\title{
Usia Ideal Perkawinan Perspektif Kompilasi Hukum Islam
}

\author{
Diyan Yusri, Alang Sidek, Cici Arianti \\ Sekolah Tinggi Agama Islam Jam'iyah Mahmudiyah, Tanjung Pura \\ Email: Diyan_Yusri@staijm.ac.id, Alang_Sidek@staijm.ac.id
}

\begin{tabular}{l}
\hline INFO ARTIKEL \\
\hline Diterima \\
2 September 2019 \\
Direvisi \\
15 November 2019 \\
Disetujui
\end{tabular}

15 Desember 2019

Kata Kunci:

Usia, Perkawinan, Hukum Islam

\begin{abstract}
ABSTRAK
Usia menikah menurut Kompilasi Hukum Islam (KHI) pasal 15 ayat 1, bagi anak laki-laki usia 19 tahun dan anak perempuan usia 16 tahun dibimbing untuk menikah di Indonesia. Menurut penulis, bahwa usia belum menikah dan membangun keluarga, pernikahan membutuhkan kesiapan usia yang matang agar dalam keluarga dapat menciptakan kualitas hubungan yang baik. Usia dewasa dalam psikologi adalah antara usia 21 sampai 30 tahun. Karena diharapkan pikiran, jiwa dan ekonominya matang. Karena perbedaan ketentuan usia tersebut menarik untuk diteliti. Rumusan masalah penelitian adalah bagaimanakah usia ideal? Pernikahan dalam Kompilasi Hukum Islam dan berapa usia ideal untuk Kompilasi Hukum Islam dalam perspektif psikologi. Tujuan yang ingin dicapai dalam penelitian ini adalah untuk mengetahui usia ideal menikah dalam Kompilasi Hukum Islam dan untuk mengetahui usia ideal Kompilasi Hukum Islam dalam perspektif psikologis. Kegunaan penelitian ini diharapkan dapat memberikan kontribusi dalam memperkaya khazanah pengetahuan dan wawasan tentang usia ideal perkawinan menurut psikologi dan KHI. Metode yang digunakan dalam penelitian kepustakaan adalah dengan memfokuskan pada kajian kepustakaan yang bersifat deskriptif, bertujuan untuk mendeskripsikan atau menjelaskan data-data yang berkaitan dengan penelitian ini. Metode analisis data cara berpikir deduktif yaitu menarik kesimpulan dari hal-hal yang umum ke suatu kesimpulan yang khusus.
\end{abstract}

\section{ABSTRACT}

Age of marriage according to the Compilation of Islamic Law (KHI) article 15 paragraph 1, for boys aged 19 years and girls aged 16 yearsguided for marriage in Indonesia. According to the author, that age has not beenmarry and build a family, marriage requiresreadiness of a mature age so that in the family can create good relationshipsquality. The mature age in psychology is between the ages of 21 to 30 years.Because it is hoped that his mind, soul and economy are mature. Because of the difference in age provisions is interesting to study.The formulation of the research problem is how is the ideal age? Marriage in the Compilation of Islamic Law and what is the ideal age for Compilation Islamic law in the perspective of psychology. Goals to be achieved in This study is to determine the ideal age of marriage in the Compilation of Islamic Law and to find out the ideal age of the Compilation of Islamic Law in psychological perspective. The usefulness of the research is expected to provide 
contribution in enriching the treasures of knowledge and insight about the ideal age of marriage according to psychology and KHI. The method used by Library research is to focus on the study bibliography, which is descriptive in nature, aims to describe or Keywords: $\quad$ explain data related to this research. The data analysis method Age, Marriage, deductive way of thinking that is drawing conclusions on general Islamic Law things to a specific conclusion.

\section{Pendahuluan}

Pernikahan merupakan sunatullah bagi manusia dalam meneruskan kehidupan. Menurut kamus Bahasa Indonesia kata ideal berarti sangat sesuai dengan yang dicita-citakan atau dianganangankan atau dikehendaki. Perkawinan menurut istilah syara" adalah ijab qabul (aqad) yang menghalalkan persetubuhan antara laki-laki dan perempuan, yang tidak ada hubungan mahram, sehingga dengan akad tersebut terjadi hak dan kewajiban antara kedua insan. Istilah ini menyebutkan perkawinan adalah sunnah karunia yang apabila dilaksanakan mendapat pahala tetapi apabila tidak dilaksanakan tidak mendapat dosa tetapi di makruhkan karena todal mengikuti sunnah Rasul (Uwaidh, 2012).

Membentuk sebuah perkawinan bukan semudah yang dibayangkan, akan tetapi memiliki makna yang sempurna yaitu sebagai suatu perjanjian lahir batin yang dilakukan oleh seorang laki-laki dan perempuan untuk hidup bersama dan melakukan kerjasama. Hal ini diwujudkan adanya rasa tanggung jawab yang meliputi hak dan kewajiban yang harus dipenuhi oleh kedua belah pihak, oleh karena itu mengingat besarnya tanggung jawab dalam mengarungi sebuah rumah tangga harus dibutuhkan kematangan psikologis kedua calon mempelai (Mufidah Ch, 2016).

Kematangan seseorang ini dapat dikaji melalui pendekatan psikologi. Psikologi secara umum adalah ilmu yang mempelajari tentang gejala-gejala kejiwaan yang berkaitan dengan jiwa manusia yang normal, dewasa, dan beradab (Jalaludin, 2013). Sehubung dengan tujuan perkawinan yakni menegakkan agama Allah SWT untuk memperoleh keturunan yang sah dengan mendirikan rumah tangga yang damai dan teratur (Ramulyo, 2015). Tujuan tersebut tidak akan tercapai apabila calon pengantin laki-laki maupun perempuan belum dewasa atau cukup umur dan belum matang jiwanya.

Perkawinan membutuhkan

kematangan yang bukan hanya bersifat biologis, melainkan juga kematangan psikologis. Perkawinan pada usia yang belum matang bagi perempuan menimbulkan berbagai resiko, baik bersifat biologis seperti kerusakan organ-organ reproduksi, kehamilan muda, dan resiko psikologis berupa ketidakmampuan mengemban fungsi-fungsi reproduksi dengan baik (Manuaba, 2014). Oleh sebab itu kehidupan keluarga menuntut adanya peran dan tanggung jawab yang besar bagi laki-laki dan perempuan (Sulostiawati, 2016).

Perkawinan merupakan aktivitas dari suatu pasangan, sehingga sudah selayaknya pasangan tersebut memiliki tujuan untuk dicapai. Namun, perkawinan terdiri dari dua individu yang berbeda, sehingga seringkali memiliki tujuan yang berbeda. Apabila terjadi perbedaan dalam tujuan, maka pasangan tersebut perlu melakukan pembulatan tujuan agar tercapainya kesatuan dalam tujuan. Tujuan yang ada dalam perkawinan perlu diresapi atau dipahami secara mendalam oleh pasangan dan disadari untuk dilakukan bersama- 
sama bukan hanya dilakukan oleh salah satu pihak (Walgito, 2012).

Dalam syariat Islam sendiri, usia untuk melaksanakan perkawinan tidak ditetapkan secara jelas dan tegas, tidak memberikan kejelasan secara pasti mengenai usia perkawinan seseorang, AlQur'an dan Hadist hanya menetapkan dugaan, isyarat dan tanda-tanda saja. Umat islam diberi kebebasan untuk menetapkan batasan usia, sehingga usia perkawinan dikembalikan pada individu tanpa melanggar syarat yang telah ditentukan, serta disesuaikan dengan kondisi sosial dimana hukum itu akan diundangkan (Kamal Mukhtar, 2013).

Umat Islam umumnya menyepakati kondisi baligh sebagai tanda yang menunjukkan seseorang telah mencapai kedewasaan, bagi perempuan adalah haidh dan laki-laki dengan mimpi basah (Sayyid Sabiq, 2016). Dilihat dari segi literature, akil baligh juga dikenal sebagai batas kematangan seksual, namun antara perempuan dan laki-laki terdapat ciri-ciri yang berbeda (Suryoprajogo, 2011). Namun juga kematangan usia perempuan dan lakilaki berpengaruh pada tingkat kesehatan seksual.

Melihat batasan usia yang telah ditetapkan dalam Kompilasi Hukum Islam pasal 15 yakni calon suami sekurangkurangnya berumur 19 tahun dan calon istri sekurang-kurangnya berumur 16 tahun. Melakukan perkawinan tanpa kesiapan dan pertimbangan yang matang dapat mengindikasikan sikap tidak apresiatif terhadap makna perkawinan. Kematangan kedua calon mempelai ini juga dimaksudkan karena perkawinan itu mengandung tujuan yang luhur yaitu menciptakan rasa tanggung jawab, mewujudkan pernikahan yang baik tanpa berujung perceraian.
Untuk mempermudah dalam
pembahasan penelitian ini, maka dirumuskan beberapa masalah; Bagaimana usia ideal perkawinan dalam Kompilasi Hukum Islam (KHI)? Bagaimana usia ideal Kompilasi Hukum Islam (KHI) dalam perspektif psikologi? Tujuan penelitian yang hendak dicapai dalam penelitian ini adalah; Untuk mengetahui usia ideal perkawinan dalam Kompilasi Hukum Islam (KHI). Untuk mengetahui usia ideal Kompilasi Hukum Islam (KHI) dalam perspektif psikologi.

\section{Metode Penelitian}

Penelitian ini merupakan penelitian pustaka (library research). Menurut Kartini Kartono penelitian pustaka (library research) yaitu metode yang digunakan bertujuan untuk mengumpulkan data-data dan informasi dengan bantuan bermacammacam materi yang terdapat dalam kepustakaan (Kartono, 2011). Dimana dalam kajian ini hanya terfokus pada dataran konsep sehingga library merupakan metode yang diterapkan dalam pengumpulan data. Penelitian ini bersifat deskriptif. Yang dimaksud deskriptif adalah suatu metode dalam meneliti suatu objek yang bertujuan membuat deskripsi, gambaran atau lukisan secara sistematis dan objektif, mengenai fakta-fakta, sifatsifat, cirri- ciri serta hubungan diantara unsur-unsur yang ada atau fenomena tertentu (Kaelan, 2015).

\section{Hasil dan Pembahasan}

Perkawinan berasal dari kata "kawin" yang menurut bahasa artinya membentuk keluarga dengan lawan jenis: melakukan hubungan kelamin atau bersetubuh. Perkawinan disebut juga "pernikahan" berasal dari kata nikah (نكاح) yang menurut bahasa artinya mengumpulkan, saling digunakan untuk arti bersetubuh 
(wathi). Kata nikah sendiri sering dipergunakan untuk arti persetubuhan (coitus) juga untuk arti kata nikah (Rahman, 2016).

Kata nikah dan zawaj tidak bisa dipisahkan, karena dalam ijab dan qabul yang dilakukan oleh wali kepada mempelai laki-laki harus mengandung kedua kata tersebut. Dalam Al-Qur"an dan Hadis, perkawinan disebut dengan al-nikah(النكاح) (الزور)

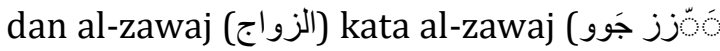
ال berasal dari akar kata zawwaja. Kata zawaj yang diartikan jodoh atau berpasangan berlaku bagi laki-laki dan perempuan; zawaj perempuan berarti suaminya sedangkan zawaj laki-laki berarti istrinya (Azzam, 2016).

Dapat disimpulkan tentang pengertian dari pernikahan yaitu akad yang menghalalkan hubungan badan antara seorang laki- laki dengan seorang perempuan yang menimbulkan kewajiban dan hak kepada keduanya setelah terjadinya akad nikah dengan tujuan untuk menjadi keluarga yang sakinnah, mawaddah dan rahmah yang diridhoi oleh Allah dan menghindari murka-Nya.

Usia perkawinan dalam Kompilasi Hukum Islam yaitu mengambil pertimbangan nilai kemanfaatan dan kemaslahatan, serta menganut prinsip bahwa calon suami istri harus telah matang jasmani dan rohaninya untuk melangsungkan perkawinan. Agar dapat memenuhi tujuan luhur serta hikmah dari perkawinan, yaitu untuk membentuk keluarga yang sakinah mawaddah dan rahmah. Pemenuhan hajat biologis serta mendapatkan keturunan. Selain nilai kemanfaatan dan kemaslahatan, kedua pasangan harus telah mencapai usia yang layak untuk melangsungkan perkawinan.

Hal ini di dukung oleh nilai kepastian hukum dan nilai keseimbangan, bahwa undang-undang tentang perkawinan menganut prinsip calon suami istri harus telah matang jiwa raganya untuk melangsungkan perkawinan agar dapat mewujudkan tujuan perkawinan secara baik tanpa berujung perceraian. Perkawinan juga mempunyai hubungan dengan masalah kependudukan, maka untuk mengurangi laju kelahiran, harus dicegah adanya perkawinan antara calon suami istri yang masih dibawah ketentuan usia yang diatur dalam Undang-Undang.

Untuk kemaslahatan warga Negara Republik Indonesia, tujuan perkawinan tidak hanya untuk berkembang biak. Rumah tangga adalah masyarakat terkecil dalam Negara. Karena keluarga yang baik maka peran keluarga akan sangat strategis dalam meningkatkan daya kembang individu ke dalam pembangunan bangsa. Keluarga membangun kualitas manusia, Kualitas manusia dalam arti yang utuh, yaitu dalam segi kesehatan, pendidikan, karakter, sikap dan lain-lain. Maka dari itu keluarga mempunyai peran sentral dalam pembentukan karakter individu dalam pembangunan bangsa. Melihat betapa pentingnya sebuah peran keluarga dalam Negara Republik Indonesia maka tentu saja yang melaksanakan perkawinan harus sudah matang jiwa raganya.

Asas penting yang diusung oleh undang-undang perkawinan Islam di dunia Islam adalah asas kematangan atau kedewasaan calon mempelai. Maksudnya, undang-undang perkawinan menganut prinsip bahwa setiap calon suami dan calon istri hendak melangsungkan akad pernikahan, harus benar-benar telah matang secara fisik maupun secara psikis (rohani), atau sudah harus siap secara jasmani dan rohani, sesuai dengan pengertian yang tertera dalam perkawinan itu sendiri, "Perkawinan adalah ikatan lahir batin antara seorang pria dengan seorang wanita." Berkaitan dengan asas 
kematangan ini, salah satu standard yang digunakan adalah penetapan usia kawin (nikah).

Ketentuan usia itu berdasarkan kebutuhan masyarakat Indonesia dan sebagai jalan tengah dari usia yang terlalu rendah dan usia yang terlalu tinggi. Tapi apakah sebenarnya ketentuan usia yang diatur oleh Kompilasi Hukum Islam ini ideal untuk melaksanakan tanggung jawab suami istri atau sebagai orang tua dan merealisasikan tujuan dari perkawinan. Walaupun secara hukum Islam dan hukum positif dinyatakan sah, akan tetapi belum dikatakan ideal karena dianggap belum mampu melaksanakan tanggung jawab suami istri atau sebagai orang tua dan merealisasikan tujuan perkawinan secara maksimal. Karena perkawinan bukan saja dibutuhkan kematangan biologis saja tetapi juga kematangan psikis dan mental.

Mengingat situasi dan kondisi zaman dan sekaligus mengingat pentingnya perkawinan di zaman modern sekarang ini, orang menikah demi kemaslahatan umat manusia. Perkawinan membutuhkan tanggung jawab dalam rumah tangga dan untuk menyelesaikan persoalan dalam rumah tangga. Karena pentingnya perkawinan termasuk untuk membina generasi yang akan datang dari setiap keluarga, maka secara tidak langsung terkandung suatu anjuran supaya siapa saja yang memasuki kehidupan rumah tangga hendaknya telah memiliki kematangan usia. Dalam hal inilah persoalan kedewasaan merupakan suatu unsur yang tidak boleh diabaikan.

Suatu perkawinan yang sukses tidak dapat diharapakan dari mereka yang mentah, baik fisik maupun mental emosional. Perkawinan meminta kedewasaan dan tanggung jawab oleh karenanya anak-anak muda sebaiknya menunggu dengan sabar sampai usia yang ideal. Dan diharapkan juga dengan memikirkan usia perkawinan secara psikologi, masyarakat Indonesia tumbuh dengan baik.

Jika disejajarkan dengan persoalan usia ideal seseorang untuk melaksanakan perkawinan, maka dalam pandangan psikologi setidaknya ditemukan bahwa aspek kedewasaan cukup relevan, jika dikaitkan dengan pembahasan usia ideal untuk perkawinan. Relevansi aspek kedewasaan sebagai usia ideal dalam perkawinan sepertinya tidaklah mudah untuk merumuskan sebuah definisi tentang kedewasaan. Kebudayaan lokal juga ikut berperan dalam upaya menentukan kriteria kedewasaan, sehingga setiap kebudayaan berbeda-beda dalam menentukan status dewasa secara formal, termasuk konsep dan definisi perkawinan. Namun demikian terdapat pandangan yang sama mengenai perkawinan, bahwa perkawinan merupakan sesuatu yang bersifat suci dan dibutuhkan dalam kehidupan.

Usia pada waktu perkawinan bukan saja bersangkutan dengan usia yang dikira matang bagi setiap individu, usia seseorang berkaitan erat dengan perkembangan psikologisnya, pertumbuhan ekonomi serta sosialnya. Menurut salah satu pakar psikologi Andi Mappiare yaitu menikah pada usia 25 sampai 30 tahun karena di usia demikian pemikiran, ekonomi dan jiwanya diharapkan sudah matang. Relasi sosial telah mencapai tingkat mapan . usia itu orang dewasa telah memiliki konsep yang matap tentang dirinya dan memiliki nilai-nilai hidup.

Ideal bagi laki-laki dan perempuan berjarak 4 tahun dengan catatan wanita lebih muda dari laki-laki. Dengan demikian usia ideal bagi perempuan yaitu usia 21 sampai 25 tahun. Di usia itu merupakan periode relative stabil dan berada di puncak kebugaran fisiknya. Sehingga dapat 
mengelola berbagai persoalan yang menghadang kelestarian kehidupan rumah tangga sangat ditentukan oleh kematangan suami istri.

Hal itu juga sejalan dengan program pemerintah yaitu Badan Kependudukan dan Keluarga Berencana Nasional (BKKBN) memberikan rekomendasi usia pernikahan yang ideal. Baiknya itu dilakukan pada usia matang 21 tahun untuk perempuan dan 25 tahun untuk laki-laki. Berdasarkan ilmu kesehatan, lanjutnya, umur ideal yang matang secara biologis dan psikologis adalah 20-25 tahun bagi wanita, kemudian umur 25-30 tahun bagi pria. Usia tersebut dianggap masa yang paling baik untuk berumah tangga, karena sudah matang dan bisa berpikir dewasa secara rata-rata.

Pernikahan yang baik merupakan di usia yang ideal, dalam bentuk psikologis maupun biologis, dan mengacu kepada tercapainya tahapan-tahapan dewasa seseorang baik dalam umurnya maupun pola berfikirnya, yang tercermin sebagaimana dia dapat memenuhi kebutuhan hidupnya, memahami peranan dirinya dalam lingkungan keluarga, masyarakat, maupun rumah tangga. Memiliki pengetahuan tentang bagaimana menata rumah tangga yang baik menurut agama dan hukum Negara, yang menjadi penentu kesiapan seseorang dalam berumah tangga.

\section{Kesimpulan}

Usia perkawinan yang ada dalam Kompilasi Hukum Islam (KHI) pasal 15 ayat 1, yakni calon suami sekurang-kurangnya 19 tahun dan calon istri sekurangkurangnya berumur 16 tahun. KHI menentukan usia itu sebagai usia kedewasaan untuk perkawinan bagi masyarakat muslim di Indonesia. Ketentuan dalam Kompilasi Hukum Islam merupakan hasil ijtihad para ulama Indonesia yang didasarkan pada pertimbangan kemaslahatan keluarga dan rumah tangga perkawinan.

Ketentuan usia perkawinan yang diatur dalam KHI bagi laki-laki 19 tahun dan bagi perempuan 16 tahun. Dilihat dalam ilmu psikologi di usia itu masih masa perkembangan remaja yang masih jauh dari kata matang dan mantap, kondisi kejiwaannya masih labil dan belum dapat dipertanggung jawabkan sebagai suami/istri apalagi sebagai orang tua yang harus merawat, mengasuh dan memberikan pendidikan. Dikhawatirkan akan menghambat pertumbuhannya dan membahayakan keselamatan anak. Kematangan fisik dan biologis erat kaitannya dengan usia perkawinan, seseorang yang menikah pada usia yang terlalu muda dapat dipastikan kematangan pikiran, fisik, dan biologisnya belum terpenuhi. Usia ideal perkawinan menurut psikologi yaitu bagi perempuan usia 21 sampai 25 tahun dan bagi laki-laki usia 25 sampai 30 tahun. Diharapkan masa yang paling baik untuk berumah tangga, karena sudah matang dan bisa berpikir dewasa secara rata-rata.

\section{Bibliografi}

Abdul Aziz Muhammad Azzam, Abdul Wahhab Sayyed Hawwas. (2016). Fiqh Munakahat. Jakarta: Amzah. Abdul Rahman Ghozali. (2016). Fiqih Munakahat. Jakarta : Kencana Prenada Media.

Ida Bagus Gde Manuaba. (2014). Ilmu Kebidanan Penyakit Kandungan dan Keluarga Berencana Untuk Pendidikan Bidan. Jakarta: Penerbit Buku Kedokteran.

Jalaludin. (2013). Psikologi Agama. Cet III. Jakarta: PT Raja Grafindo Persada. 
Kaelan M.s. (2015). Metode Penelitian Kualitatif Bidang Filsafat. Yogyakarta: Paradigma.

Kamal Mukhtar. (2013). Asas-asas Hukum Perkawinan. Cet 3. Jakarta: Bulan Bintang.

Kartini Kartono. (2011). Pengantar Metologi Riset Sosial. Cet VII. Bandung: Mandar Maju.

Mufidah Ch. (2016). Psikologi Keluarga Islam Berwawasan Gender. Malang: UIN Maliki Press.

Muhammad Idris Ramulyo. (2015). Hukum Perkawinan Islam. Jakarta: Bumi Pustaka.
Nadine Suryoprajogo.(2011). Kupas Tuntas Kesehatan Remaja. Yogyakarta: Diglossia Printika.

Sayyid Sabiq. (2016). Fikih Sunnah 6. Terjemahan Moh. Thalib. Bandung: PT Al Ma'rif.

Syaikh Kamil Muhammad Uwaidh. (2013). Fiqh Wanita. Jakarta: Al-Kautsar.

Sulostiawati S. (2016). Perempuan dan Hukum (Menuju Hukum yang Berperspektif Kesetaraan dan Keadilan). Jakarta: Yayasan Obor Indonesia.

Walgito B. (2012). Bimbingan dan Konseling Perkawinan. Jakarta: CV Andi

Offset.

Copyright holder :

Diyan Yusri, Alang Sidek, Cici Arianti (2020).

First publication right :

Action Research Literate

This article is licensed under: 